\title{
PENDOKUMENTASIAN BENDA BERSEJARAH SECARA DIGITAL 3D \\ (Studi Kasus Museum Universitas Kristen \\ Maranatha)
}

\author{
I Nyoman Natanael*1, Raden Ajeng Dita Saraswati ${ }^{2}$ \\ Desain Komunikasi Visual, Fakultas Seni Rupa dan Desain, Universitas Kristen Maranatha \\ Correspondence author: nyoman.natanael@art.maranatha.edu, Bandung, Indonesia
}

\begin{abstract}
Abstrak. Teknologi pemindaian 3D memiliki peran penting dalam membantu mendokumentasikan artefak bersejarah secara digital. Kemajuan teknologi tersebut dapat dimanfaatkan untuk berbagai bidang salah satunya bidang pendidikan. Dengan teknologi ini memungkinkan peneliti atau institusi untuk memiliki aset digital objek penting dengan dokumentasi yang lebih baik dan juga dapat memberikan informasi kepada generasi berikutnya dengan pendekatan yang lebih menarik. Penelitian ini mendokumentasikan benda-benda bersejarah yang tersimpan di ruang museum secara digital tiga dimensi. Studi kasus museum yang dipilih adalah Museum Universitas Kristen Maranatha yang terletak di kota Bandung. Museum Universitas Kristen Maranatha memiliki banyak koleksi benda-benda bersejarah yang dapat memberikan nilai \& informasi yang akurat dan bermanfaat bagi seluruh civitas akademika di lingkungan Universitas Kristen Maranatha dan juga masyarakat luas. Hasil penelitian ini berupa aset visual dapat dikembangkan lebih lanjut untuk perancangan media digital interaktif seperti museum virtual. Metode yang digunakan berupa survei dan eksperimen dengan proses pendokumentasian benda-benda bersejarah yang dibuat menyerupai benda aslinya, baik dalam bentuk geometris, dimensi maupun teksturnya. Objek museum akan dipindai menggunakan teknik 3D scanning, fotogrametri, dan fotografi, yang kemudian direkonstruksi menjadi objek tiga dimensi.
\end{abstract}

Kata Kunci: Pemindaian 3D, Fotogrametri, Museum.

\begin{abstract}
D scanning technology has an important role in helping to digitally document historic artifacts. These technological advances can be used for various fields, one of which is education. With this technology, it allows researchers or an institution to have digital assets of important objects with better documentation and can also provide information to the next generation with a more interesting approach. This research documents historical objects stored in the museum rooms in a three-dimensional digital manner. The case study of the museum chosen is the Maranatha Christian University Museum which is located in the city of Bandung. The Maranatha Christian University Museum has a wide collection of historical objects that can provide accurate and useful value \& information for the entire academic community in the Maranatha Christian University environment and also the wider community. The results of this research in the form of visual assets can be further developed for the design of interactive digital media such as virtual museums. The method used is in the form of surveys and experiments with the process of documenting historical objects that are made closer to the original objects, both in their geometric shapes, dimensions and textures. Museum objects will be scanned using 3D scanning, photogrammetric, and photography techniques, which are then reconstructed into threedimensional objects.
\end{abstract}

Keywords: 3D Scanning, Fotogrametri, Museum 


\section{Pendahuluan}

Pemanfaatan teknologi digital, khususnya 3D scanning pada benda bersejarah di museum sudah banyak diterapkan di berbagai negara, dengan berbagai tujuan antara lain sebagai pengembangan penelitian dan pelestarian artefak bersejarah. Hal ini digunakan untuk mendokumentasikan dan menyampaikan informasi kepada generasi mendatang melalu kemasang media yang sesuai dengan perkembangan jaman. Seperti pada museum yang memiliki koleksi benda bersejarah, museum yang terdapat pada institusi pendidikan seperti perguruan tinggi juga memiliki koleksi benda bersejarah yang penting diketahui bagi generasi muda. Menurut Kuntowidjojo (Kuntowijoyo, 2005) disebutkan bahwa sejarah merupakan ilmu yang mempunyai makna sosial yang penting bagi perkembangan dan perubahan masyarakat. Melalui catatan sejarah dapat memotivasi seseorang untuk berbuat lebih baik dari nenek moyangnya. Bahkan terpenting dalam pemahaman peristiwa masa lalu, akan menggugah kesadaran sejarah yang bersifat kolektif yaitu bentuk pengalaman bersama sebagai ungkapan reaksi mereka kepada situasi dalam peristiwa sosial politik, ekonomi, kebudayaan dari masa ke masa. Dengan mempelajari sejarah, generasi muda akan banyak mengetahui apa yang terjadi pada masa lalu dan pengaruhnya dengan kehidupan masa kini.

Demikian juga dengan Museum Universitas Kristen Maranatha yang dijadikan sebagai studi kasus pada penelitian ini, dimana Museum U.K. Maranatha memiliki lebih dari 50 benda koleksi yang dipajang di dalam sebuah area pamer berukuran sekitar 36 meter persegi. Setiap benda koleksi tersebut memiliki kisah sejarah mengenai awal berdirinya Universitas Kristen Maranatha. Koleksi benda bersejarah yang terdapat di dalam Museum U.K Maranatha menjadi relevan dan dianggap penting untuk diteliti karena memiliki informasi yang perlu disampaikan kepada segenap Civitas Akademika tentang sejarah berdiri dan perjalanan U.K Maranatha. Namun benda koleksi tiga dimensi yang dipamerkan dalam suatu museum seringkali memiliki penataan yang statis dan dikurung, dibatasi dengan sejumlah pembatas baik berbahan kaca, akrilik yang bertujuan menghindari sentuhan dari para pengunjung. Penataan secara statis tidak memungkinkan bagi pengungjung untuk dapat melihat keseluruhan bagian sisi dari benda tersebut karena mungkin saja benda koleksi dipajang menempel pada dinding atau tidak dipajang di atas media display berputar. Hal tersebut dapat dipengaruhi dari jumlah benda koleksi yang dimiliki untuk dipamerkan serta berkaitan dengan ketersediaan luas ruangan yang akan digunakan sebagai area pamer dari benda koleksi museum.

Benda koleksi museum dapat dihadirkan kepada pengunjungnya baik secara fisik, maupun non-fisik (virtual). Benda koleksi yang dipamerkan di museum pada umumnya memiliki bentuk struktur objek tiga dimensional, namun ketika objek tersebut didokumentasikan secara dua dimensional (foto) maka ada informasi yang tidak dapat dimunculkan secara lengkap. Seiring dengan berkembangnya teknologi, khususnya pendokumentasian suatu objek dengan menggunakan teknik 3D scanning atau photogrammery diyakini dapat hadir sebagai solusi atas permasalahan tersebut. Pendokumentasian benda koleksi dalam bentuk digital tiga dimensi memiliki potensi yang sangat luas. Benda yang nantinya telah didokumentasikan dapat dipergunakan secara luas sebagai suatu aset visual ke dalam media berbasis interaksi seperti Augmented Reality (AR), Virtual Reality (VR), game digital, maupun berupa film animasi.

\section{Metode}

Metode yang digunakan dalam melakukan pendokumentasian secara digital tiga dimensi tersebut dimulai dengan melakukan pendataan secara tertulis mengenai benda-benda koleksi 
yang memungkinkan untuk dilakukan pendokumentasian. Kemudian dilanjutkan dengan melakukan pengambilan data visual berupa kumpulan foto dan pemindaian tiga dimensi dari setiap benda koleksi yang nantinya akan digunakan dalam tahap rekonstruksi tiga dimensi. Proses rekonstruksi tiga dimensi tersebut terbagi ke dalam tiga metode antara lain menggunakan teknik fotogrametri, pemindaian 3D dan modeling 3D secara konvensional. Objek tiga dimensi hasil rekonstruksi yang memiliki jumlah titik (verteks) yang sangat banyak kemudian direduksi dengan menggunakan software perangkat lunak 3D sehingga setiap objek tiga dimensi memiliki tingkat detail yang berbeda (Level of Detail/LOD), tergantung pada jumlah verteksnya. Kemudian selanjutnya dilakukan proses penyempurnaan atau perbaikan (refining) jika diperlukan. Pendekatan luaran yang hendak dicapai dalam penelitian ini adalah menghasilkan objek digital tiga dimensi mendekati seperti benda aslinya dengan menggunakan perangkat lunak antara lain Capturing Reality, MeshLab dan Blender kemudian juga menggunakan perangkat keras kamera mobile phone Oppo A92 serta 3D scanner Sense II.

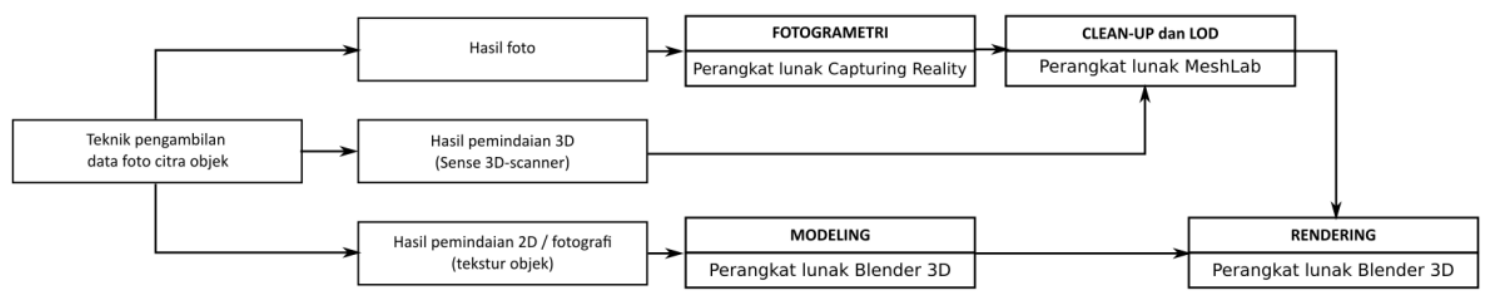

Gambar 1 Skema proses pendokumentasian digital 3D (Penulis)

\section{Pemindaian 3D dan Fotogrametri}

Konsep 3 dimensi adalah sebuah penggambaran yang memiliki sistem koordinat dengan sumbu $X, Y, Z$. Arah dari sumbu $Y$ adalah tegak, sumbu $X$ adalah lurus, dan sumbu $Z$ adalah tinggi atau kombinasi diantaranya sesuai dengan arah yang dikehendaki (Banowosari, Wibowo, \& Syafril, Pembuatan Museum Virtual Budaya dan Sejarah, 2012). Bentuk 3 dimensi dihasilkan dalam proses komputer grafis dengan dua cara, yang pertama menggunakan manual modeling, yang kedua menggunakan $3 \mathrm{~d}$ scanning. Jika manual modeling adalah membangun objek dari nol, maka $3 \mathrm{~d}$ scanning adalah proses pemindai sebuah objek nyata kemudian direkonstruksi menjadi format komputer grafis 3 dimensi.

Pemindaian 3D adalah teknologi yang berkembang dan banyak digunakan untuk perangkat pemindaian untuk berbagai aplikasi. Meskipun tergolong baru, pemindaian 3D secara luas diterima sebagai cara yang efektif, akurat, dan cepat untuk mengumpulkan dan menganalisis data pengukuran. Faktanya, tingkat detail yang dapat ditangkap pemindaian 3D menjadikannya metode pilihan untuk banyak aplikasi (Q-Plus Lab, 2016). Jika dikaitkan dengan artefak benda bersejarah, digitalisasi 3 dimensi (pencitraan 3D atau pemindaian 3D) dianggap teknik yang penting dalam pendokumentasian dan menganalisa benda cagar budaya (Wachowiak \& Karas, 2009).

Ada beberapa teknik dalam pemindaian 3 dimensi, yang paling banyak digunakan adalah teknik Contact 3D Scanning, Non-Contact Active dan Non-Contact Passive. Teknik Contact 3D Scanning digunakan untuk objek yang sederhana atau kecil. Proses pemindaian menggunakan alat analisa yang menyentuh fisik objek dalam beberapa posisi yang telah ditentukan dan model 3D yang dihasilkan adalah berupa sekumpulan titik pada posisinya sama antara alat dan objek yang disentuh. Non-Contact Active menggunakan perangkat yang memancarkan cahaya dan mengukur waktu yang diperlukan untuk kembali ke perangkat, dan dengan cara itu, perangkat merekonstruksi jarak dari pemindai untuk semua titik pada objek. Contoh perangkat seperti pemindai laser, LiDAR (Light Detection and Ranging) dan pemindai yang menggunakan cahaya terstruktur (Structured Light Scanners). Perangkat tersebut cukup mahal tetapi sangat 
presisi. Kelemahannya adalah, saat memindai objek yang lebih besar sangat memakan waktu dan tenaga karena tidak memungkinkan jika objek dipindai pada ruang yang sempit. Sedangkan untuk teknik Non-Contact Passive, menggunakan perangkat yang menerima cahaya (seperti kamera foto dan video) kemudian perangkat merekonstruksi objek 3D dengan menggunakan foto yang dibuat dari berbagai sudut di sekitar objek tersebut. Pendekatan ini paling sederhana untuk digunakan, tetapi bergantung pada banyak faktor: kualitas sensornya, kondisi pencahayaan, jumlah foto yang dibutuhkan dalam jumlah besar, pengalaman operator, dan juga perangkat lunak yang dapat mengubah foto menjadi model 3D dan Fotogrametri adalah salahsatu yang menggunakan pendekatan ini (Reljic \& Dunder, 2019).

Fotogrametri adalah ilmu untuk memperoleh informasi yang dapat dipercaya tentang sifat permukaan objek tanpa kontak fisik dengan objek tersebut untuk diukur atau ditafsirkan. Fotogrametri adalah disiplin ilmu teknik dan karenanya sangat dipengaruhi oleh perkembangan ilmu komputer dan elektronik. Penggunaan komputer yang semakin meningkat telah dan akan terus berdampak besar pada fotogrametri (Schenk, 2005).

Istilah "fotogrametri" berasal dari tiga kata Yunani yaitu phos atau phot yang artinya cahaya, gramma yang artinya huruf atau sesuatu yang digambar dan kata benda dari pengukuran. Pengambilan data dalam fotogrametri berkaitan dengan keandalan dalam perolehan informasi pada permukaan dan objek. Hal Ini dicapai tanpa kontak fisik dengan objek yang memiliki perbedaan paling jelas. Informasi yang diterima dari jarak jauh dapat dikelompokkan menjadi empat kategori, yaitu:

1. Informasi Geometris; melibatkan posisi spasial dan bentuk objek. Ini adalah sumber informasi terpenting dalam fotogrametri.

2. Informasi Fisik; mengacu pada sifat radiasi elektromagnetik, misalnya radiasi energi, panjang gelombang, dan polarisasi.

3. Informasi Semantik; berkaitan dengan arti suatu gambar. Biasanya diperoleh dengan menafsirkan data yang direkam.

4. Informasi Temporal; terkait dengan perubahan suatu objek dalam waktu, biasanya diperoleh dengan membandingkan beberapa gambar yang direkam pada waktu yang berbeda. (Schenk, 2005)

Pengambilan foto yang akan digunakan dalam proses fotogrametri perlu memperhatikan beberapa prinsip, antara lain:

1. Pengambilan foto antara satu foto dengan foto berikutnya harus memiliki bagian yang saling tumpang tindih kira-kira dua per tiga atau 65-75\%, sehingga komputer dapat menangkap citra objek yang sama melalui sudut dan posisi yang berbeda. Perbedaan tersebutlah yang akan dijadikan data.

2. Pengambilan foto dilakukan sebanyak mungkin dari berbagai sudut pandang dan berbagai ketinggian. Pengambilan foto tersebut dilakukan dengan cara mengelilingi objek, setiap perpindahan posisi kamera memiliki setidaknya bergeser 15 derajat.

3. Pengaturan kamera menggunakan tingkat ISO rendah (100-500) agar dapat menghasilkan foto yang tajam. Kecepatan tombol shutter diatur dengan kecepatan tinggi, sehingga tidak menghasilkan foto yang blur.

4. Pencahayaan pada objek harus merata pada setiap bagian objek, hindari pencahayaan yang berlebih sehingga menimbulkan terlalu banyak pantulan pada objek. Apabila mengambil foto di luar ruangan, hindari objek terpapar sinar matahari langsung.

\section{Level of Detail (LOD)}

Level of Detail (LOD) adalah sebuah disiplin dari komputer grafis interaktif yang berupaya untuk menjembatani antara kompleksitas dan performa dengan mengatur jumlah detail yang digunakan untuk merepresentasikan bentuk virtual dalam teknologi $3 \mathrm{~d}$ modeling. 
LOD memiliki tiga kerangka dasar pengaturan, yaitu Discrete, Continuous, dan View-Dependent LOD (Luebke, et al., 2003). Dalam bahasan LOD dijabarkan mengenai teknik bahwa objek 3D memiliki beragam resolusi diukur dari jumlah titik (vertices) yang membentuk objek 3D tersebut (high/low polygon). Beragam LOD yang dimiliki oleh sebuah objek 3D biasanya digunakan untuk memberikan efisiensi memori (RAM) komputer dalam sebuah software game-engine. Sebagai contoh objek 3D yang dilihat dari dekat akan secara otomatis menggunakan LOD dengan resolusi tinggi, demikian juga sebaliknya objek 3D yang dilihat dari jauh akan secara otomatis menggunakan objek 3D dengan resolusi rendah.

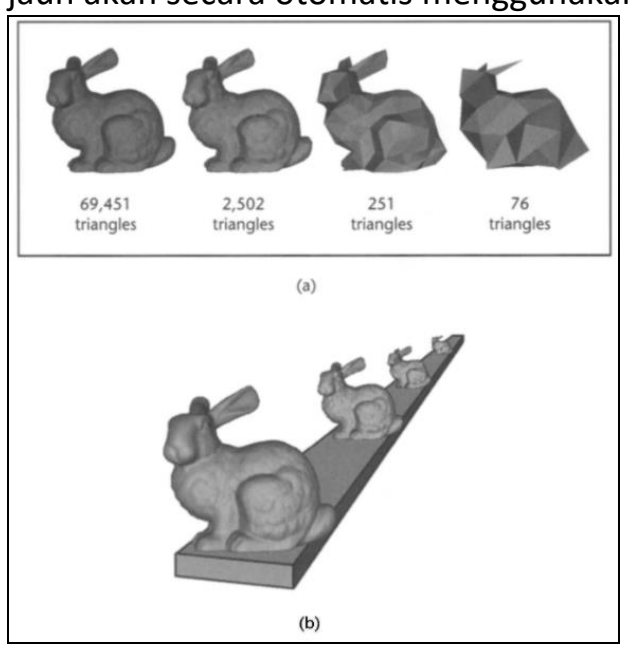

Gambar 2 Level of Detail dari sebuah objek tiga dimensi (Luebke, et al., 2003)

\section{Discrete $L O D$}

Merupakan pendekatan yang paling tradisional. Pendekatan ini digunakan sebagaimana aslinya pada tahun 1976 hingga saat ini. Pendekatan ini membuat beberapa versi dari setiap objek, masing-masing pada tingkat detail yang berbeda selama proses offline. Pada saat runtime detail level yang sesuai, atau LOD, dipilih untuk mewakili objek. Karena objek yang letaknya jauh menggunakan LOD yang cenderung lebih kasar, maka jumlah poligon akan berkurang dan kecepatan rendering meningkat. LOD ini memiliki banyak keunggulan. Penyederhanaan dan perenderan Decoupling menjadikannya model yang paling sederhana untuk diprogram: Simplification Algorithm dapat membutuhkan waktu selama yang diperlukan untuk menghasilkan LOD dan algoritme perenderan waktu proses (Run-Time Rendering) hanya perlu memilih LOD mana yang akan dirender untuk setiap objek.

\section{Continuous $L O D$}

Berangkat dari pendekatan yang tradisional, alih-alih membuat LOD individu, Continuous LOD ini dalam sistem penyederhanaannya membuat struktur data yang mengkodekan spektrum detail secara berkelanjutan (Continuous). Tingkat detail yang diinginkan diekstraksi dari struktur ini saat run-time. Keuntungan utama dari pendekatan ini adalah perincian (granularity) yang lebih baik: karena tingkat detail untuk setiap objek ditentukan secara tepat daripada dipilih dari beberapa opsi yang dibuat sebelumnya, sehingga poligon digunakan sesuai dengan yang diperlukan.

\section{View-Dependent $L O D$}

LOD view-dependent bersifat anisotropik: satu objek dapat menjangkau beberapa tingkat penyederhanaan. Misalnya, bagian terdekat dari objek mungkin menunjukkan resolusi yang lebih tinggi daripada bagian yang jauh, pada bagian siluet dari objek menunjukkan resolusi yang lebih tinggi daripada bagian interior / dalam. Hal ini mengarah pada granularity 
yang lebih baik, artinya poligon dialokasikan di tempat yang paling dibutuhkan di dalam objek, serta di antara objek.

\section{Penelitian Terdahulu}

Penelitian ini merupakan lanjutan dari penelitian sebelumnya yang berjudul "Kajian User Experience Pemain Terhadap Aspek Realisme Dalam Game Digital 3D Bergenre Role-Play First Atau Third Person" lebih membahas pada pengalaman unik yang diperoleh pemain, sehingga nantinya menjadi referensi dan pertimbangan dalam pembuatan game maupun simulasi untuk mengomunikasikan serta melestarikan kebudayaan lokal kepada generasi masa kini. Dalam penelitian tersebut didapatkan bahwa aspek realisme mungkin memang dibutuhkan untuk menambah atau memperkuat atribut immersion yang dapat membuat player memiliki pengalaman yang semakin berkesan, terhanyut dalam game namun tetap bahwa gameplay tetap akan memberikan pengalaman pemain (Player Experience) terbaik. (Natanael \& Aryani, 2019). Hubungan antara penelitian mengenai pendokumentasian benda koleksi museum secara 3D dengan menggunakan pendekatan realistis diyakini akan dapat memberikan pengalaman senyata mungkin ketika objek 3D tersebut digunakan nantinya dalam pengembangan museum secara virtual.

Penelitian ini juga merupakan salah satu upaya pelestarian sejarah yang merujuk pada penelitian sebelumnya yang berjudul "Perancangan Grafis dan Interior Museum Batik Tiga Negeri Lasem". Dalam penelitian ini dipaparkan mengenai upaya pelestarian artefak atau objek sejarah yang berbentuk sebuah kain batik, motif, benda 3 dimesi lainnya yang berciri khas budaya Tionghoa peranakan. Selain konsep besar museum yang lebih menggunakan pemaparan secara naratif, dalam artikel ini pula dgunakan media digital interaktif seperti motion graphic, Augmented Reality (AR) dan Virtual Reality (VR) sebagai upaya untuk menyampaikan informasi sejarah dengan lebih berinteraksi dengan pengunjung juga sebagai solusi untuk peremajaan konsep museum yang sudah terkesan kuno. Salah satu kesimpulan dalam artikel ini adalah pentingnya keselarasan konsep keseluruhan bagi grafis visual maupun interior museum serta dukungan dari teknologi multimedia yang sangat signifikan untuk penyampaian informasi kepada target yang lebih muda. (Saraswati, Rismantojo, Halim, \& Tjandradipura, 2019). Dalam penelitian ini juga dilakukan wawancara kepada Ir. Slamet Taslim selaku narasumber untuk memperoleh data mengenai deskripsi lengkap mengenai setiap benda koleksi yang terdapat di dalam Museum Universitas Kristen Maranatha.

\section{Hasil dan Pembahasan}

Berikut ini adalah pemaparan dari hasil penelitian yang dirunutkan sesuai dengan prosesnya, dimulai dari proses pendataan, pemindaian 3D dan pengambilan foto untuk proses fotogrametri, pengolahan pada perangkat lunak, termasuk tahap pengolahan fotogrametri, clean-up objek hasil pemindaian 3D atau fotogrametri, pembuatan LOD dan video rotasi 360 derajat sebagai tinjauan objek 3D yang telah selesai direkonstruksi.

\section{Hasil Pendataan Benda Koleksi Museum}

Terdapat 11 benda yang akan direkonstruksi menjadi objek 3D dengan menggunakan teknik fotogrametri dan 33 benda lainnya yang menggunakan teknik 2D-3D Scanning serta manual modeling 3D. Jumlah foto yang diperoleh untuk merekonstruksi objek 3D dengan teknik fotogrametri dipengaruhi oleh ukuran benda. 
Tabel 1 Daftar benda yang direkonstruksi dengan menggunakan teknik fotogrametri

\begin{tabular}{|r|l|r|}
\hline No & \multicolumn{1}{|c|}{ Nama Objek } & Jumlah foto \\
\hline 1 & Mesin Ketik Hitam & 296 \\
\hline 2 & Timbangan & 264 \\
\hline 3 & Microscope & 240 \\
\hline 4 & Proyektor 8mm Besar & 215 \\
\hline 5 & Gulungan Film & 55 \\
\hline 6 & Mesin Ketik Putih & 252 \\
\hline 7 & Mesin Stensil & 209 \\
\hline 8 & Tinta Mesin Stensil & 42 \\
\hline 9 & Komputer Pertama & 86 \\
\hline 10 & Proyektor 8mm Kodak Tutup & 97 \\
\hline 11 & Proyektor 8mm Kodak Buka & 201 \\
\hline \multicolumn{2}{|l|}{ Sumber: Penulis }
\end{tabular}

Tabel 2 Daftar benda yang direkonstruksi dengan menggunakan teknik 2D-3D scanning

\begin{tabular}{|r|l|c|c|}
\hline No & \multicolumn{1}{|c|}{ Nama Objek } & 2D & 3D \\
Scanning & Scanning \\
\hline 1 & Jarum Suntik & & V \\
\hline 2 & Jarum Suntik - Tempat jarum suntik & & V \\
\hline 3 & Jarum Suntik - Jarum & $\mathrm{V}$ & $\mathrm{V}$ \\
\hline 4 & Stamp 1 Persegi Panjang - Sastra & $\mathrm{V}$ & $\mathrm{V}$ \\
\hline 5 & Stamp 2 Persegi Panjang - Psikologi & $\mathrm{V}$ & $\mathrm{V}$ \\
\hline 6 & Stamp 3 Persegi Panjang - Elektro & $\mathrm{V}$ & $\mathrm{V}$ \\
\hline 7 & Stamp 4 Bundar Hijau - Sastra & $\mathrm{V}$ & $\mathrm{V}$ \\
\hline 8 & Stamp 5 Bundar Coklat - Fakultas Kedokteran & $\mathrm{V}$ & $\mathrm{V}$ \\
\hline 9 & Pin 1 Mabin 86 & $\mathrm{V}$ & \\
\hline 10 & Pin 2 Panitia Biru & $\mathrm{V}$ & \\
\hline 11 & Pin 3 Bridge 2 & $\mathrm{V}$ & \\
\hline 12 & Pin 4 FTE UKM Open Tournament & $\mathrm{V}$ & \\
\hline 13 & Pin 5 Mabim FTE 88 & $\mathrm{V}$ & \\
\hline 14 & Pin 6 Panitia Opspek \& OKK 89-90 & $\mathrm{V}$ & \\
\hline 15 & Pin 7 Pin Ospek Merah & $\mathrm{V}$ & \\
\hline 16 & Pin 8 Hima Elektro - Slamet Taslim & $\mathrm{V}$ & \\
\hline 17 & Buku Nyanyian Pekan Orientasi Study & $\mathrm{V}$ & \\
\hline 18 & Buku Mapram 1970 & $\mathrm{V}$ & \\
\hline 19 & Buku Nyanyian Pra Mahasiswa 68 & $\mathrm{V}$ & \\
\hline 20 & Buku Mapram 67 & $\mathrm{V}$ & \\
\hline 21 & Kartu Undangan 11 September 1965 & $\mathrm{V}$ & \\
\hline 22 & Kuitansi Tiang Bendera 1965 & $\mathrm{V}$ & \\
\hline 23 & Buku Sejarah Berdirinya Maranatha - Suatu Kesaksian & $\mathrm{V}$ & \\
\hline 24 & Buku Peresmian GSG PA Surjadi 1990 & $\mathrm{V}$ & \\
\hline 25 & Buku Rencana Induk Pengembangan 1984-1989 & $\mathrm{V}$ & \\
\hline 26 & Majalah Mahasiswa Mei 1973 & $\mathrm{V}$ & \\
\hline 27 & Sempoa & $\mathrm{V}$ & $\mathrm{V}$ \\
\hline & & & \\
\hline
\end{tabular}




\begin{tabular}{|c|l|c|c|}
28 & Roll Film 8mm PA Suryadi & $\mathrm{V}$ & \\
\hline 29 & Dok Surat Undangan Rapat 27 Desember 1964 & $\mathrm{V}$ & \\
\hline 30 & Dok Surat Keputusan 13 Januari 1965 & $\mathrm{V}$ & \\
\hline 31 & Dok Surat hasil Rapat 29 Desember 1964 & $\mathrm{V}$ & \\
\hline 32 & Stamp Press & & $\mathrm{V}$ \\
\hline 33 & Album Foto & & $\mathrm{V}$ \\
\hline
\end{tabular}

Sumber: Penulis

Hasil Pengambulan Foto Benda dan Pemindaian 3D

1. Fotogrametri

Berikut merupakan hasil foto dari masing-masing objek, pengambilan foto dari setiap objek dilakukan dengan cara mengelilingi dan dari sudut pandang berbeda.

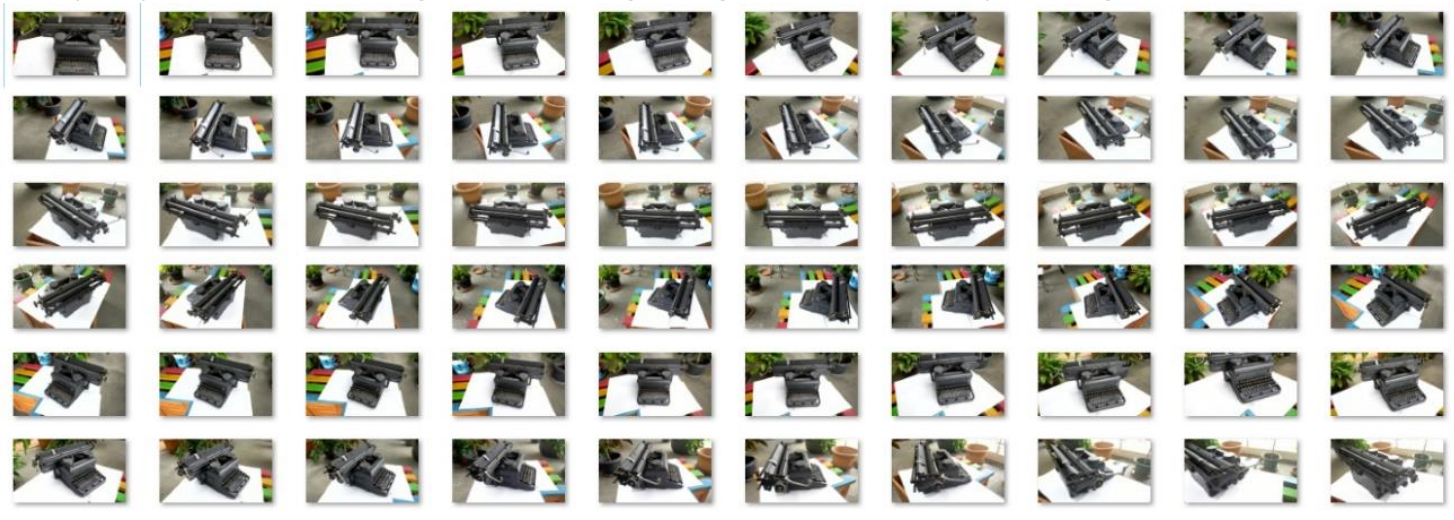

Gambar 3 Proses pengambilan kumpulan foto benda mesin ketik hitam (Penulis)
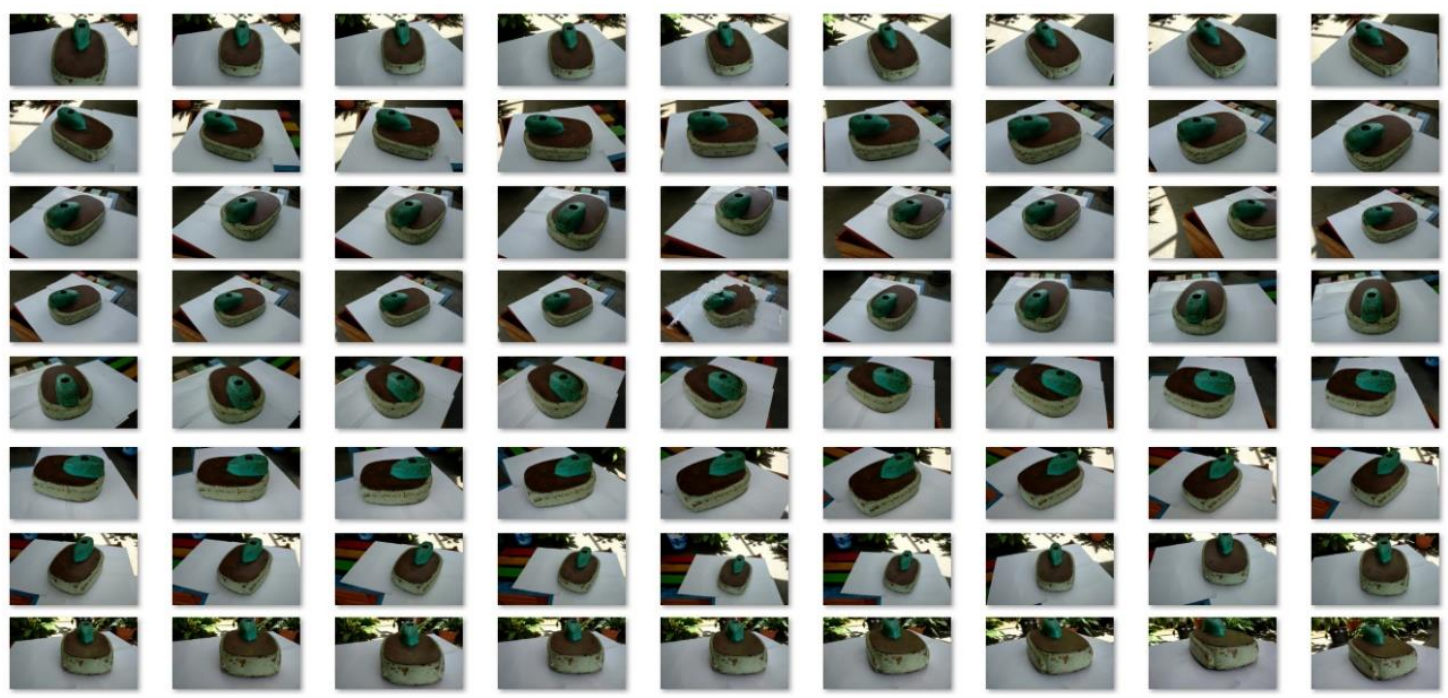

Gambar 4 Proses pengambilan kumpulan foto benda timbangan badan (Penulis)

2. Pemindaian 2D dan 3D

Proses pemindaian benda dengan menggunakan teknik scanning secara 2D maupun $3 \mathrm{D}$ dilakukan terhadap benda yang memiliki ketebalan yang tipis, kemudian pengambilan foto maupun scanning 2D juga dilakukan untuk memperoleh tekstur benda. 


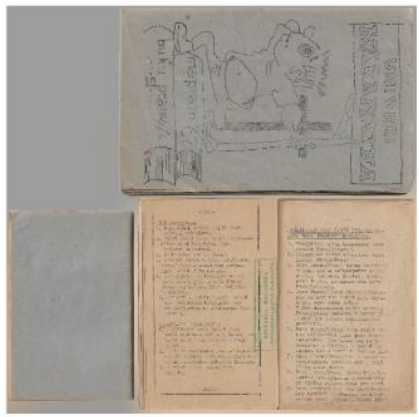

Gambar 5 Hasil pemindaian 2D pada benda buku untuk memperoleh tekstur (Penulis)

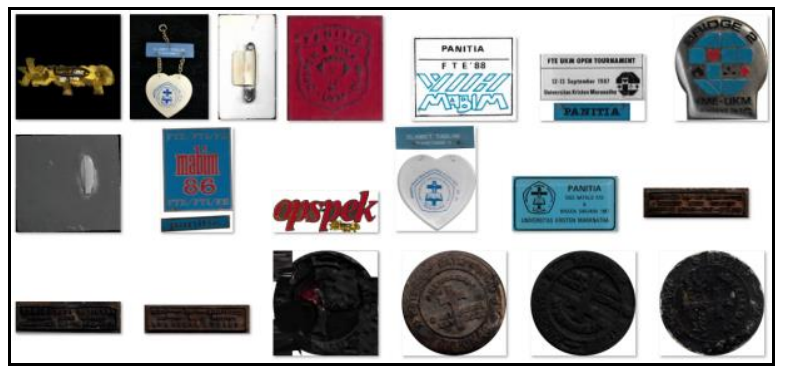

Gambar 6 Hasil pemindaian 2D pada benda pin dan stempel untuk memperoleh tekstur (Penulis)

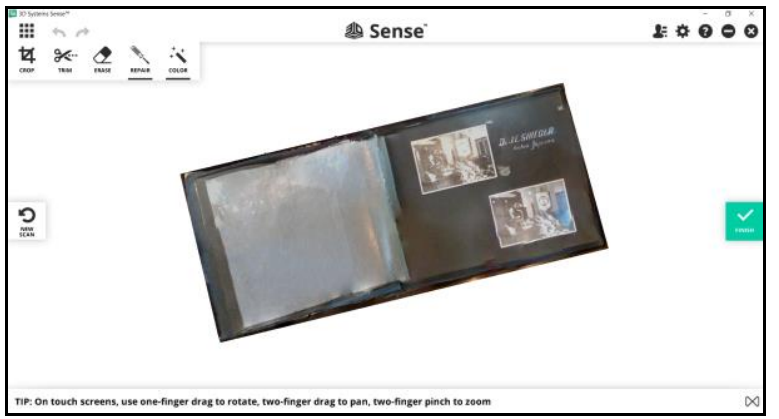

Gambar 7 Hasil pemindaian 3D pada benda album foto dengan menggunakan Sense II. (Penulis)

\section{Hasil Pengolahan pada Perangkat Lunak}

Langkah selanjutnya untuk seluruh objek yang telah selesai difoto dan dipindai baik secara 2D dan 3D, dilakukan pengolahan pada perangkat lunak yang berbeda meliputi tahap rekonstruksi, clean-up hingga pembuatan Level of Detail (LOD). Dikarenakan data hasil pemindaian 3D menggunakan 3D-scanner sudah diperoleh data objek tiga dimensinya, maka proses rekonstruksinya dilanjutkan langsung pada proses clean-up/ refining.

\section{Rekonstruksi di Reality Capture}

Reality Capture dipilih dan digunakan dalam penelitian ini dikarenakan memiliki kemampuan yang sangat baik dalam melakukan proses rekonstruksi serta mampu menghasilkan objek 3D dengan sangat baik. 


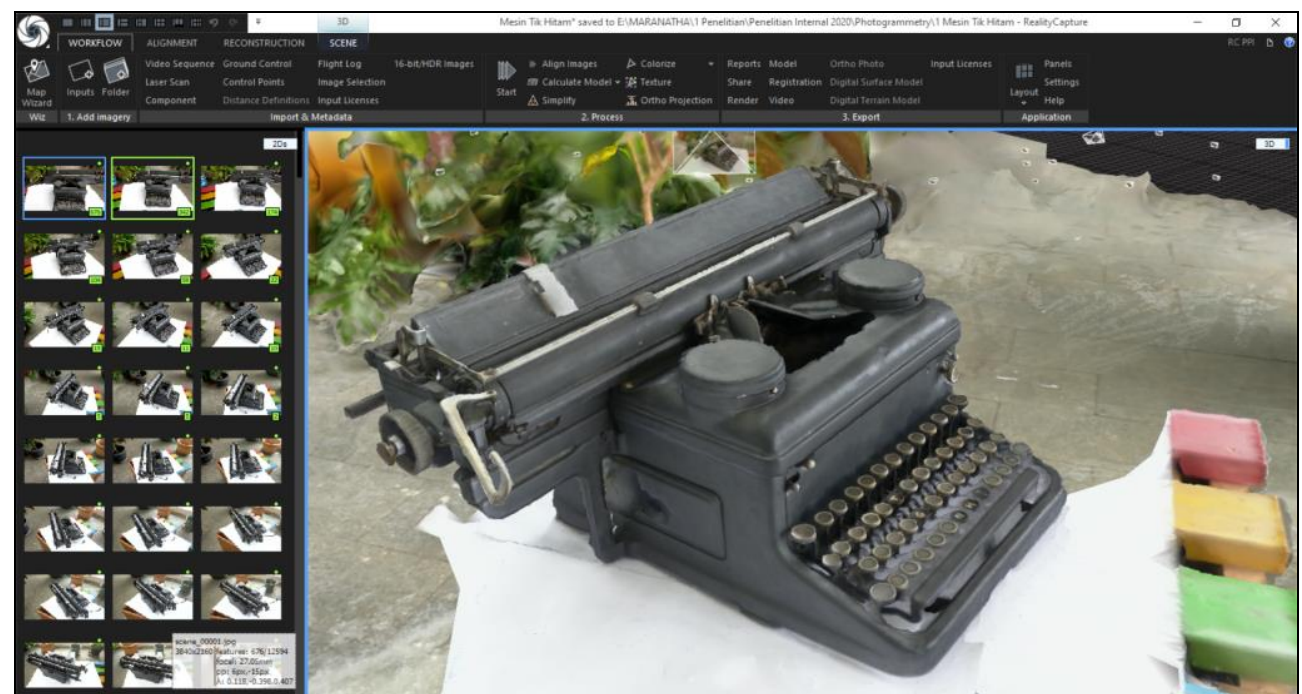

Gambar 8 Hasil rekonstruksi objek 3D dengan menggunakan Reality Capture (Penulis)

2. Hasil Clean-Up di MeshLab

Proses clean-up dilakukan untuk menghilangkan bagian pada hasil rekonstruksi objek yang tidak diperlukan pada objek tersebut. Proses ini dilakukan pada perangkat lunak Meshlab dengan cara menghapus titik (verteks) pada objek. MeshLab dipilih dikarenakan memiliki kemampuan dalam mengolah objek 3D dengan kompleksitas dan jumlah verteks yang sangat banyak.

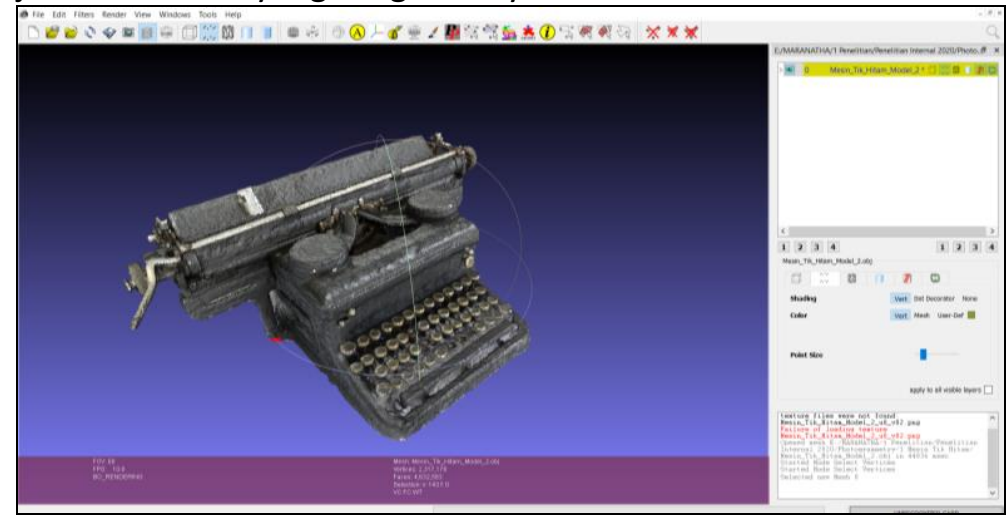

Gambar 9 Hasil clean-up objek 3D di MeshLab (Penulis)

3. Hasil Pemrosesan Level of Detail (LOD)

Objek 3D yang merupakan hasil rekonstruksi dari fotogrametri dapat memiliki jumlah vertek yang sangat banyak hingga jutaan, sedangkan dalam penggunaan yang bertujuan untuk animasi, game jumlah verteks yang sangat banyak akan menyulitkan dan tidak efisien. Sehingga dengan demikian objek 3D harus dikurangi jumlah verteksnya agar dapat digunakan secara optimal. Prinsip pembuatan LOD dalam penelitian ini menggunakan teknik pengurangan atau reduksi verteks sebanyak $50 \%$ dari jumlah verteks semula, hingga ditemukan jumlah verteks dalam jumlah minimal namun masih memberikan bentuk geometris objek secara optimal. Proses pembuatan tingkat Level of Detail (LOD) ini dilakukan pada perangkat lunak Blender. 


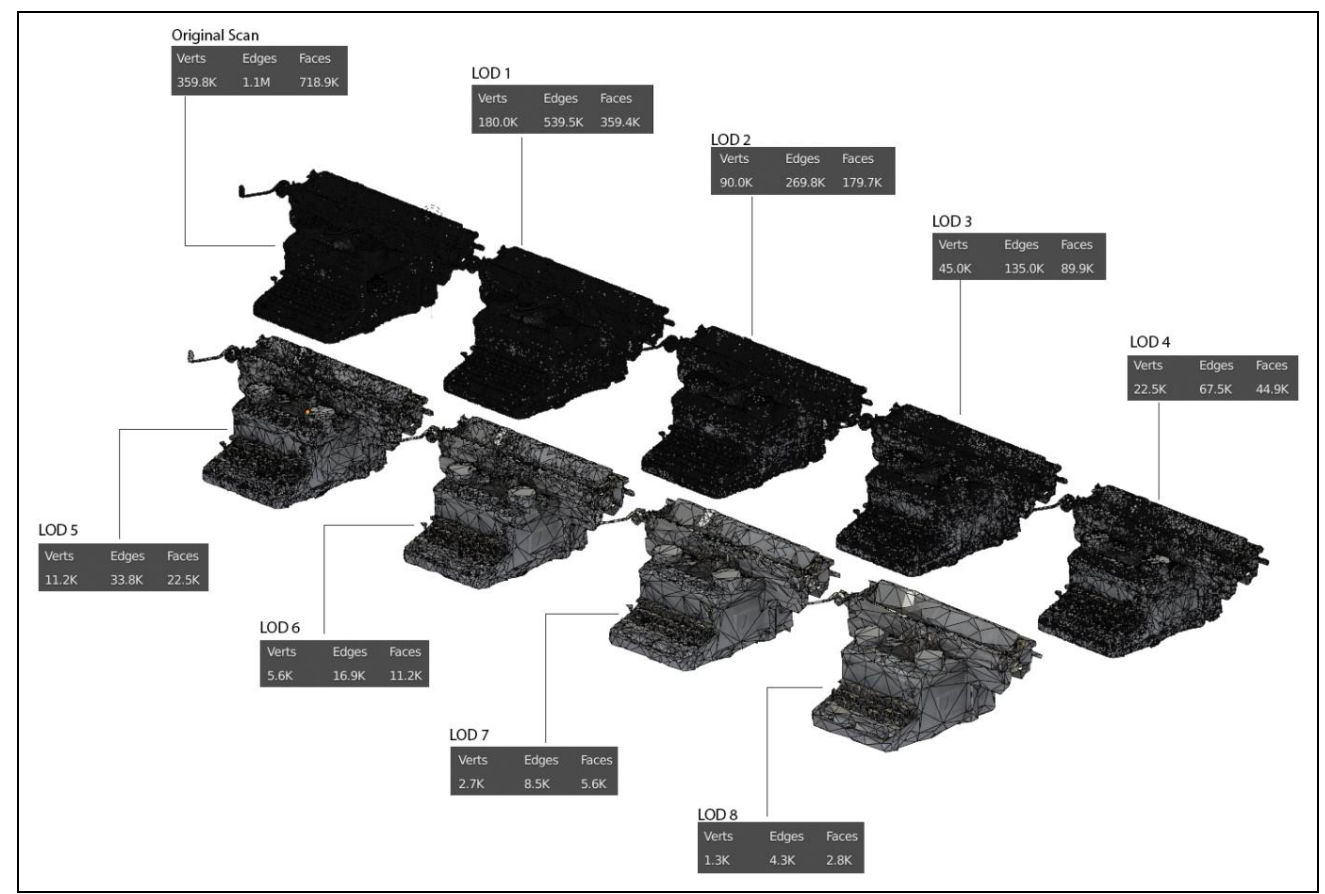

Gambar 10 Hasil pemrosesan LOD pada objek 3D mesin ketik hitam. (Penulis)

Dari Gambar 10 di atas, dapat terlihat bahwa hasil objek 3D hasil rekonstruksi dari Reality Capture yang telah di clean-up di perangkat lunak MeshLab memiliki jumlah verteks sebanyak 359.000 titik atau sebanyak 718 poligon (face). Kemudian setelah dilakukan LOD sebanyak delapan kali, maka verteks objek berhasil direduksi sampai berjumlah 1.300 titik atau memiliki 2.800 poligon saja.

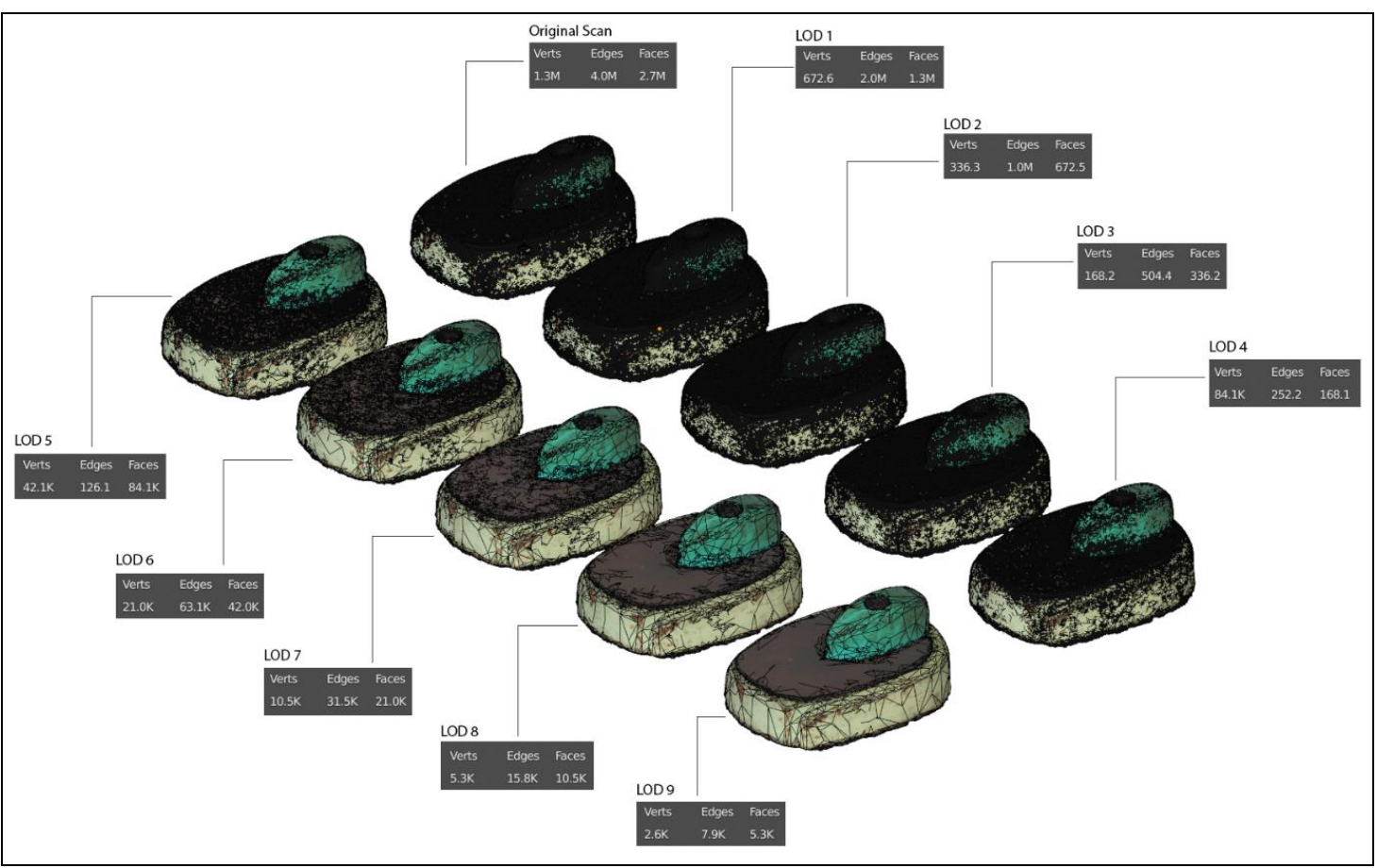

Gambar 11 Hasil pemrosesan LOD pada objek 3D timbangan. (Penulis) 
Secara umum, LOD diperlukan jika objek 3D memiliki jumlah yang sangat banyak, untuk objek hasil rekonstruksi lainnya yang tidak memiliki jumlah dalam rentang optimum (1.000 - 20.000 verteks) untuk keperluan animasi dan game maka tidak dilakukan pembuatan tingkat LOD. Objek 3D yang dihasilkan melalui proses pemindaian 2D/3D untuk memperoleh tekstur dan direkonstruksi secara manual dengan memberikan ketebalan objek melalui proses modeling, tidak memiliki jumlah verteks yang sangat banyak, sehingga tidak perlu dilakukan pembuatan tingkat LOD.

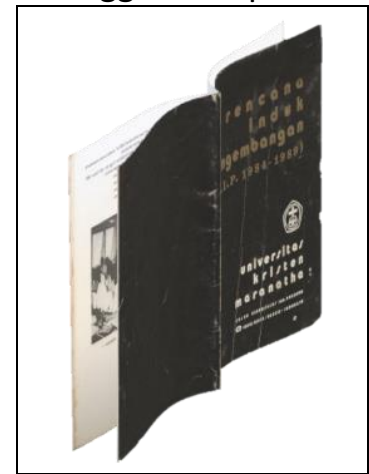

Gambar 12 Objek 3D dari hasil pemindaian 2D tidak membutuhkan LOD. (Penulis)

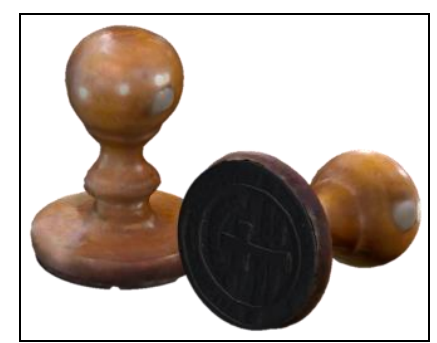

Gambar 13 LOD tidak diperlukan pada objek 3D yang memiliki jumlah verteks sedikit

\section{Hasil Rekonstruksi Benda Museum Menjadi Objek 3D}

Objek 3D yang telah selesai direkonstruksi kemudian dibuat dalam bentuk preview video berotasi 360 derajat untuk memperlihatkan setiap sudut dan bagian dari hasil rekonstruksi objek tersebut. Pembuatan video tersebut dilakukan menggunakan perangkat lunak Blender 3D. Berikut adalah hasil rekonstruksi benda museum menjadi objek 3D, untuk dapat melihat video preview 360 derajat dapat melakukan pemindaian pada setiap QR-code berikut dengan menggunakan aplikasi pembaca QR-code (QR-code reader) dari smartphone.

Tabel 3 Hasil rekonstruksi objek 3D dalam format video rotasi $360^{\circ}$. (Penulis)

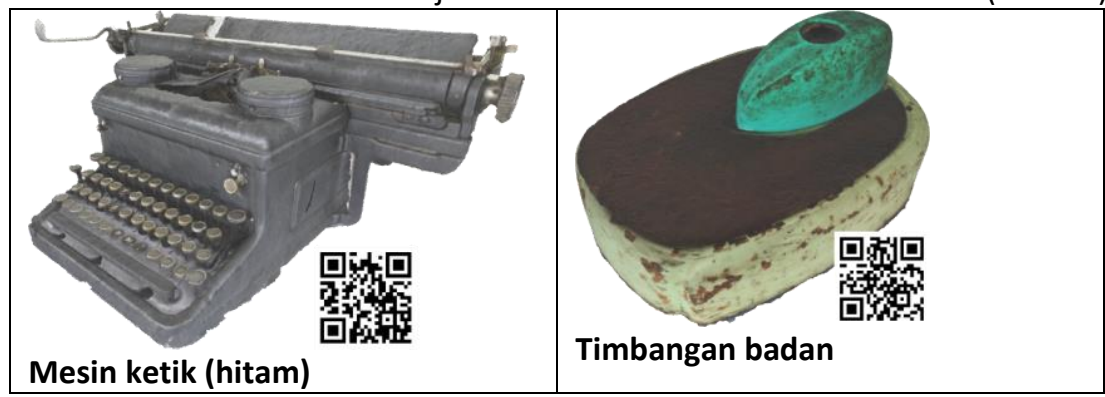




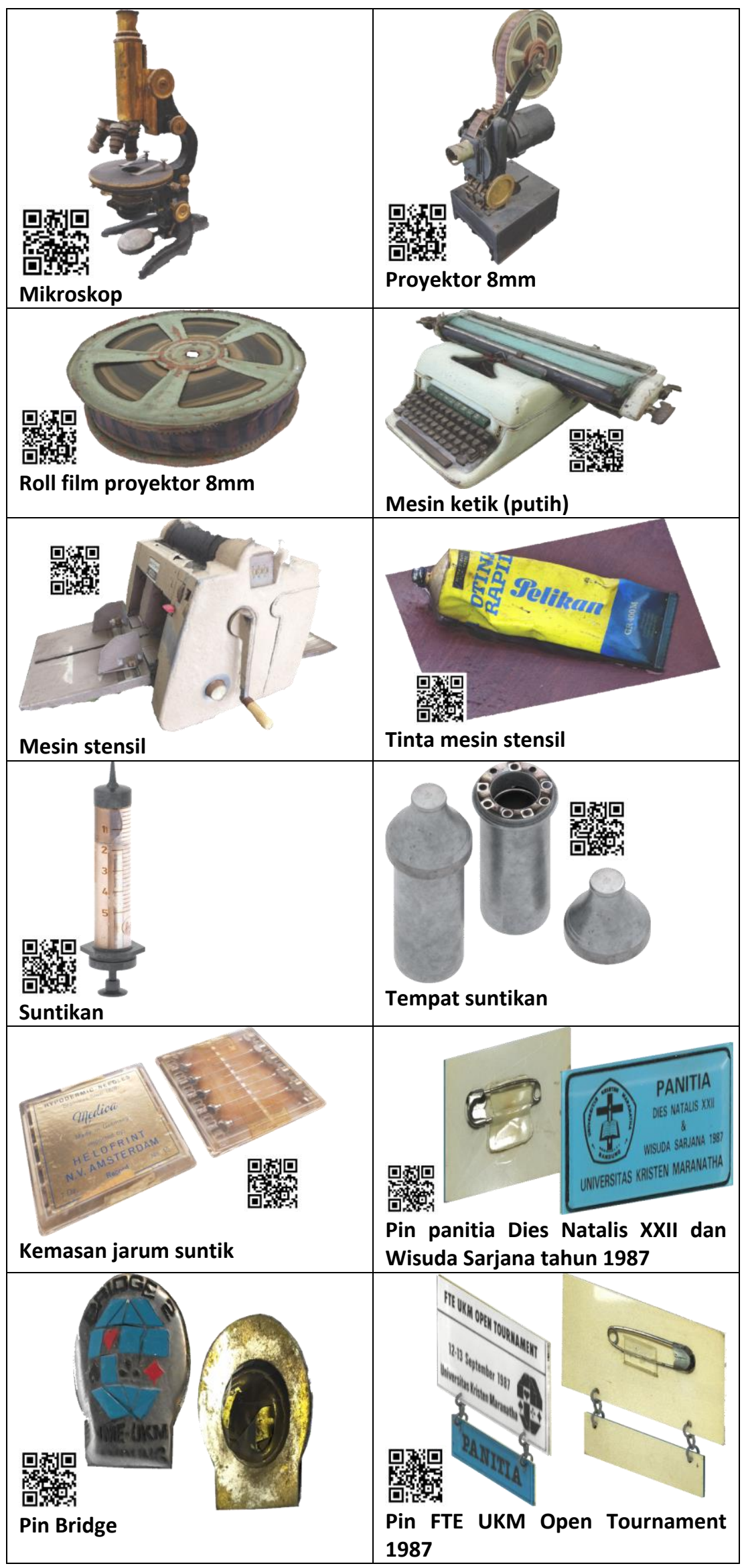




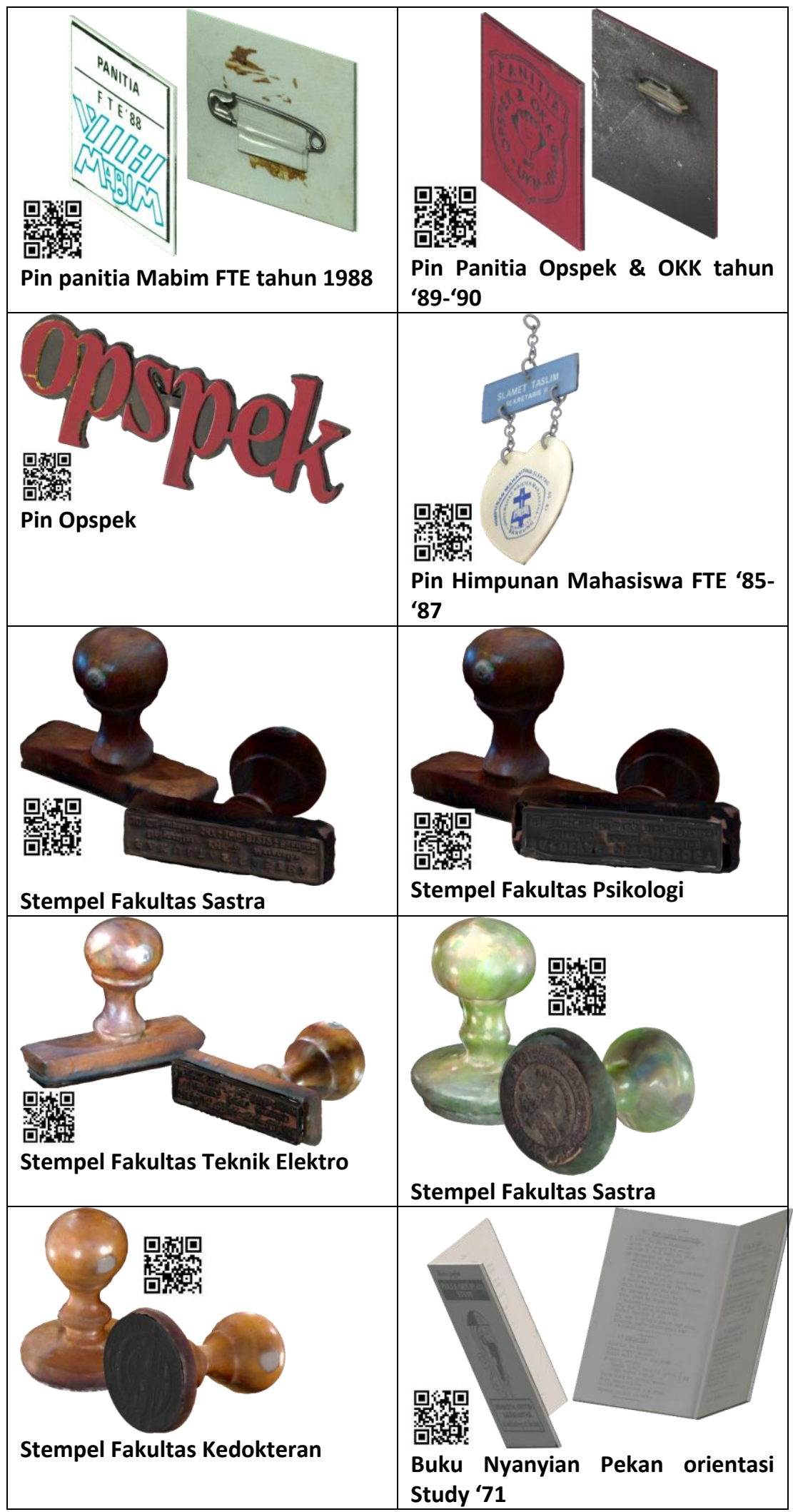




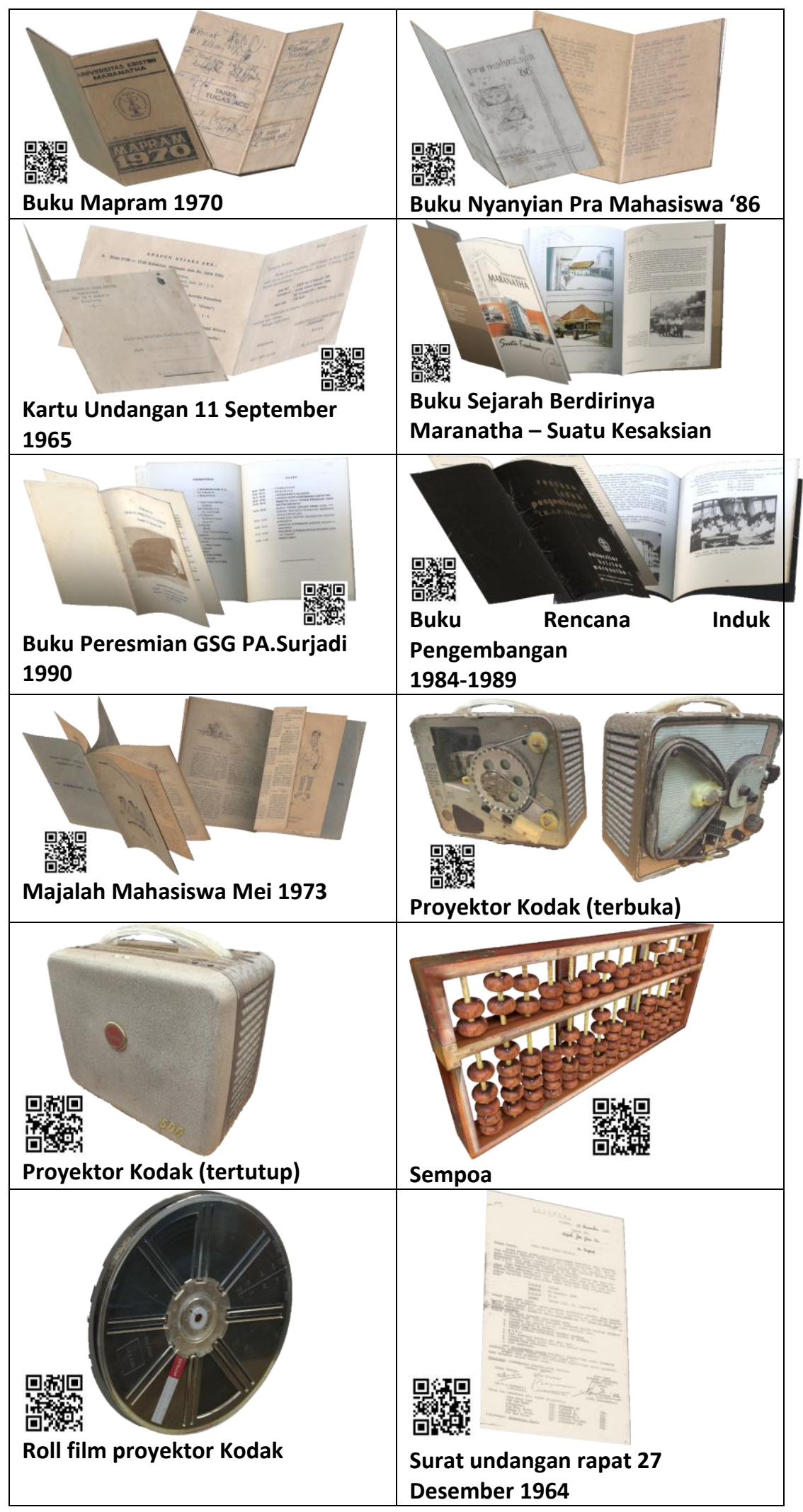




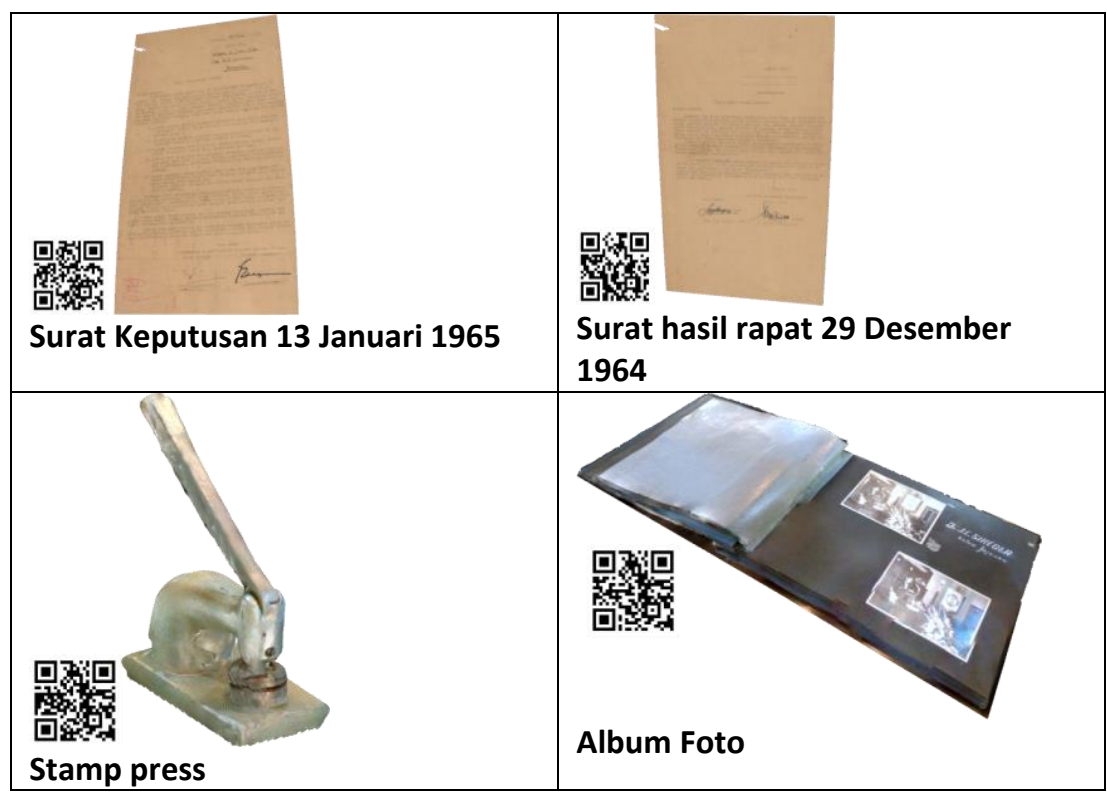

\section{Simpulan}

Adapun simpulan yang dapat dihasilkan dari penelitian ini antara lain adalah

1. Pendokumentasian secara digital tiga dimensi benda museum, khususnya Museum Maranatha sangat penting dilakukan sebagai salah satu pelestarian sejarah dan kebudayaan terutama dimasa kini, dimana aspek informasi dan teknologi sudah semakin maju. Hal tersebut perlu terus dikembangkan sebagai upaya adaptasi perkembangan teknologi dan transfer pengetahuan dan sejarah khususnya pada generasi muda dan mendatang secara khusus dalam lingkup civitas akademika Universitas Kristen Maranatha.

2. Masih terdapat benda-benda koleksi Museum Maranatha yang belum terdokumentasikan secara digital tiga dimensi, belum memiliki keterangan dan deskripsi yang lengkap serta beberapa gulungan film belum dikonversi ke dalam format digital. Hal tersebut dapat menjadi hambatan ketika suatu saat akan digunakan sebagai bagian dari pengembangan museum virtual.

3. Hasil pengolahan objek 3D yang direkonstruksi, baik menggunakan teknik pemindaian tiga dimensi, maupun fotogrametri yang merupakan aset digital dengan tingkat LOD yang berbeda nantinya dapat digunakan media pembelajaran digital serta penyebaran pengetahuan dalam bentuk media interaktif seperti Augmented Reality (AR), Virtual Reality, game digital, 3d printing dan film animasi.

\section{Daftar Pustaka}

Banowosari, L. Y., Wibowo, A. W., \& Syafril, F. F. (2011). Pembuatan Museum Virtual Budaya dan Sejarah. Universitas Gunadarma.

Banowosari, L. Y., Wibowo, A. W., \& Syafril, F. F. (2012, Mei 5). Pembuatan Museum Virtual Budaya dan Sejarah. Retrieved from Repository Publikasi Gunadarma: http://publication.gunadarma.ac.id/handle/123456789/923

Caine, M., Contessa, A., \& Grinberg, Z. (2015). The 3D Scanning of The Mantua Ark. EVA London Conference. London. 
Kuntowijoyo. (2005). Pengantar Ilmu Sejarah. Yogyakarta: Bentang Pustaka.

Luebke, D., Reddy, M., Cohen, J. D., Varshney, A., Watson, B., \& Huebner, R. (2003). Level of Detail for 3D Graphics. San Fransisco, California, USA: Morgan Kaufmann.

Natanael, I. N., \& Aryani, D. I. (2019). Kajian User Experience Pemain Terhadap Apek Realisme dalam Game Digital 3D Bergenre Role-Play First atau Third Person. Dimensi, 11.

Q-Plus Lab. (2016, April 2). A Multi-Dimensional Look at 3D Scanning : When, Why, and How to Use it. Retrieved from scribd.com: https://www.scribd.com/document/306740488/3DScanning-Book

Reljic, I., \& Dunder, I. (2019). Application of Photogrammetry in 3D Scanning of Physical Objects. TEM Journal Vol.8, Issue 1, 94-101.

Saraswati, R. D., Rismantojo, S., Halim, E. A., \& Tjandradipura, C. (2019). Perancangan Grafis dan Interior Museum Batik Tiga Negeri Lasem Jawa Tengah. SENDIMAS 2019 . Vol.4 No.1, pp. 342-348. Semarang: Universitas Katolik Soegijapranata.

Schenk, T. (2005). Introduction to Photogrammetry. Ohio: Department of Civil and Environmental Engineering and Geodetic Science, Ohio State University.

Wachowiak, M. J., \& Karas, B. V. (2009). 3d Scanning and Replication for Museum and Cultural Heritage Applications. Journal of teh American Institute for Conservation, 48(2), 141158. 